\title{
Successful Mechanical Thrombectomy in a 2-Year- Old Male Through a 4-French Guide Catheter
}

\author{
David A. Stidd, MD, MS, Demetrius K. Lopes, MD
}

A 2-year-old boy with hypoplastic left heart syndrome that required multiple cardiovascular surgeries and a heterozygous prothrombin G20210A mutation with resulting thrombophilia maintained on warfarin presented with acute right middle cerebral artery (MCA) infarction manifesting as a left hemiplegia. An MRI revealed a complete occlusion of the right M1 segment with an area of restricted diffusion in the right basal ganglia representing only a small area of acute infarction. Patchy areas of subacute infarction were also present in the right MCA territory. He underwent endovascular mechanical thrombectomy with a stent retriever. This is an account of a successful mechanical thrombectomy performed in the youngest patient reported in the English literature to date.

Key Words : Acute ischemic stroke; Coagulopathy; Mechanical thrombectomy; Pediatric acute ischemic stroke; Stent retriever

Acute ischemic stroke (AIS) is a rare disease in childhood, lowering physician suspicion for pediatric AIS and delaying prompt diagnosis. Accurate diagnosis is further confounded by multiple stroke mimics including postictal paresis, demyelinating pathologies, and migraine headaches, which are more common in pediatric patients [1]. This delay of diagnosis and treatment contributes to the high associated morbidity of pediatric AIS that can lead to lasting neurologic deficits persisting into adulthood. Pediatric patients are excluded from current AIS trials and treatment recommendations are made on a case-by-case basis or

All authors: Department of Neurosurgery, Rush University Medical Center, Chicago, IL, USA

Received August 1, 2014; accepted after revision August 25, 2014.

Correspondence to: Demetrius K. Lopes, MD

Rush University Medical Center, 1725 W. Harrison Street, Suite 855, Chicago, Illinois 60612, USA

Tel. 1.312.563.3394 Fax. 1.312.942.2176

E-mail: brainaneurysm@mac.com

This is an Open Access article distributed under the terms of the Creative Commons Attribution Non-Commercial License (http://creativecommons.org/licenses/by-nc/3.0) which permits unrestricted non-commercial use, distribution, and reproduction in any medium, provided the original work is properly cited. extrapolated from adult studies. Mechanical thrombectomy can potentially serve as a safe method to rapidly recanalize an occluded cerebral vessel. This is a report of a successful mechanical thrombectomy performed in a 2-year-old patient and a review of the available literature.

\section{CASE PRESENTATION}

\section{History and Presentation}

This 2 year-old Hispanic male has a past medical history of hypoplastic left heart syndrome (HLHS) that required multiple cardiothoracic surgeries including a Norwood procedure with a Sano shunt after birth, a bidirectional Glenn procedure at 4 months of age, and two subsequent tricuspid valve repairs. He had a right middle cerebral artery (MCA) stroke at 18 months of age manifesting as left face and arm weakness. At that time, a heterozygous prothrombin G20210A mutation was diagnosed causing thrombophilia. The stroke was medically managed. He ultimately made a full neurologic recovery and was discharged home with warfarin for the thrombophilia.

He was most recently admitted for acute left hemiple- 
gia. At 1430 on the day of presentation, his mother noted that he was demonstrating some left-sided weakness that progressed to complete hemiplegia. At 1800 in the emergency department, his mentation and speech were appropriate, but the left hemiplegia persisted and his modified Rankin scale (mRS) was 4. His anticoagulation was subtherapeutic with an INR of 1.6. Suspecting a stroke, a head CT scan was obtained demonstrating an area of hypodensity within the inferior right frontal lobe suggestive of a recent infarct. To obtain more information, the patient was electively intubated and an emergent MRI was obtained (Fig. 1), demonstrating a complete occlusion of the proximal right M1 segment. An area of restricted diffusion was noted deep to the insular cortex involving the right lentiform nucleus and posterior limb of the internal capsule. Patchy areas of restricted diffusion were demonstrated in right frontal region and posterior temporo-occipital junction without corresponding hypointensity on the ADC map indicating subacute areas of infarction.

\section{Endovascular Intervention}

Given the findings of the MRI, the patient was urgently transferred to the endovascular suite for intervention. He remained intubated and under general anesthesia while access was obtained in the right common femoral artery with a 4F sheath. A $65 \mathrm{~cm}-$ length, 4F angled Glidecath (Terumo Medical Corporation, Somerset, NJ), was navigated into the right internal carotid artery (ICA) over a 0.035 inch Glidewire (Terumo Medical Corporation, Somerset,
NJ) without difficulty given the history of aortic arch reconstruction. An angiogram obtained from a right ICA injection (Fig. 2A) confirmed the occluded proximal M1 segment. A Trevo Pro 14 microcatheter (Stryker, Kalamazoo, MI) was navigated through the guide catheter into the right ICA over a Synchro 14 micro-guidewire (Stryker, Kalamazoo, MI). The microguidewire was then carefully advanced through the M1 segment thrombus followed by the microcatheter over the guidewire and an angiogram was obtained through the microcatheter after the guidewire was withdrawn (Fig. 2B), confirming position of the catheter. A $3 \times$ $20 \mathrm{~mm}$ Trevo XP ProVue Retriever stent (Stryker, Kalamazoo, MI) was then deployed into the occluded M1 segment (Fig. 2C). After approximately 3 minutes, the stent retriever and microcatheter were withdrawn together as a unit through the $4 \mathrm{~F}$ guide catheter in the ICA. An angiogram obtained after the pass (Fig. 3A and $3 \mathrm{~B}$ ) revealed that the $\mathrm{M} 1$ segment was still occluded and a thrombus fragment had migrated into the right anterior cerebral artery (ACA).

After the failed first pass of the stent retriever, a larger $4 \times 20 \mathrm{~mm}$ Trevo XP ProVue Retriever stent was deployed into the right M1 segment using a Trevo Pro 18 microcatheter that was first passed through the M1 thrombus over a Synchro 14 microwire (Fig. 3C). After deployment of the stent, the microcatheter was carefully withdrawn out of the groin over the stent pusher wire, leaving only the stent retriever and $4 \mathrm{~F}$ guide catheter in place. Gentle aspiration was then applied to the guide catheter after 3 minutes while the stent retriever was carefully withdrawn from the M1
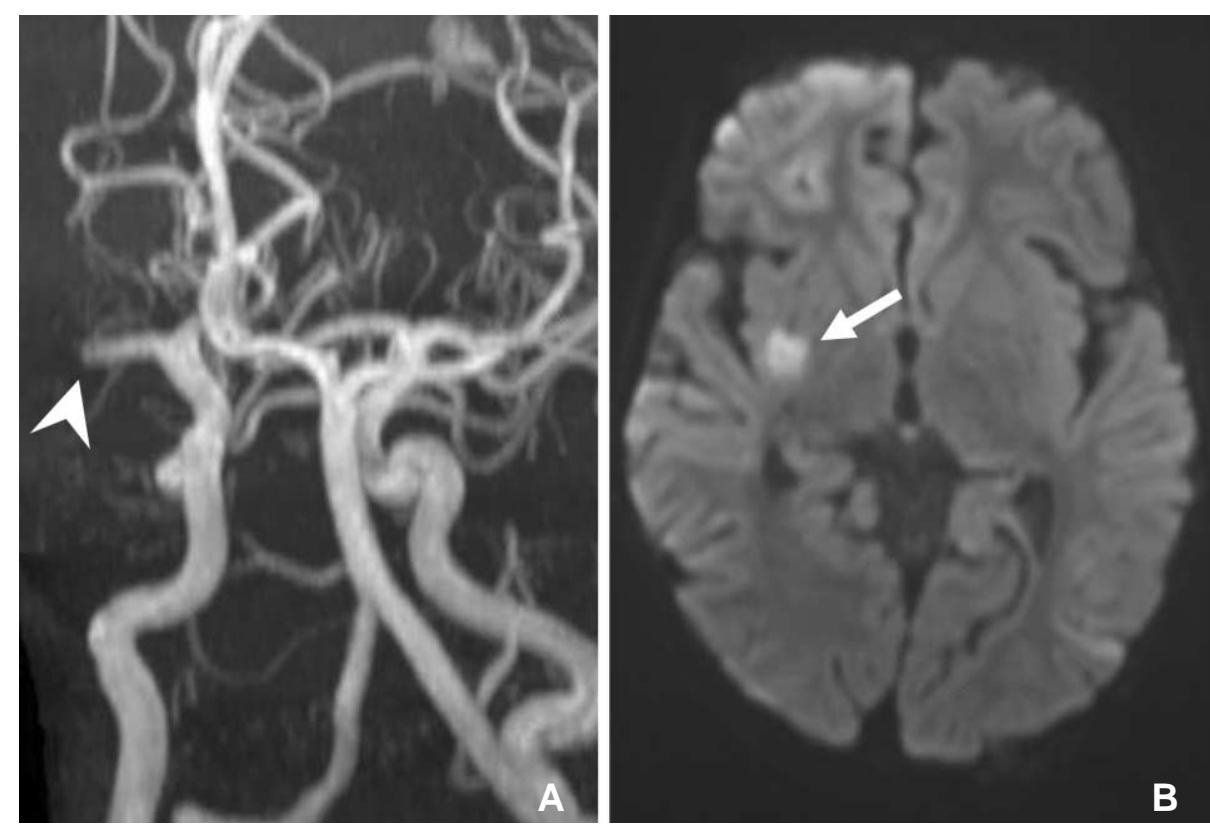

Fig. 1. A. Maximum intensity projection from a time-of-flight MRA demonstrating an occlusion of the proximal right $\mathrm{M} 1$ segment (arrowhead). B. Diffusion weighted $\mathrm{MRI}$ demonstrating restricted diffusion within the right lentiform nucleus and posterior limb of the internal capsule (arrow). 


\section{David A. Stidd, et al.}

segment into the $4 \mathrm{~F}$ catheter in the ICA. A subsequent angiogram showed partial recanalization of the M1 segment. This procedure was repeated for a third pass in the M1 segment. A $4 \times 20 \mathrm{~mm}$ stent retriever was once again deployed into the M1 clot and the microcatheter was withdrawn. Aspiration was applied to the 4F guide catheter as the stent was withdrawn, resulting in a TICI $2 \mathrm{~b}$ recanalization of the right $\mathrm{MCA}$ territory (Fig. 4A).

Next, attention was turned to the right ACA thrombus (Fig. 4B). Using the same technique, a $4 \times 20 \mathrm{~mm}$ stent retriever was deployed through the ACA thrombus after a microcatheter was passed through the clot over a microwire (Fig. 4C). The microcatheter was then
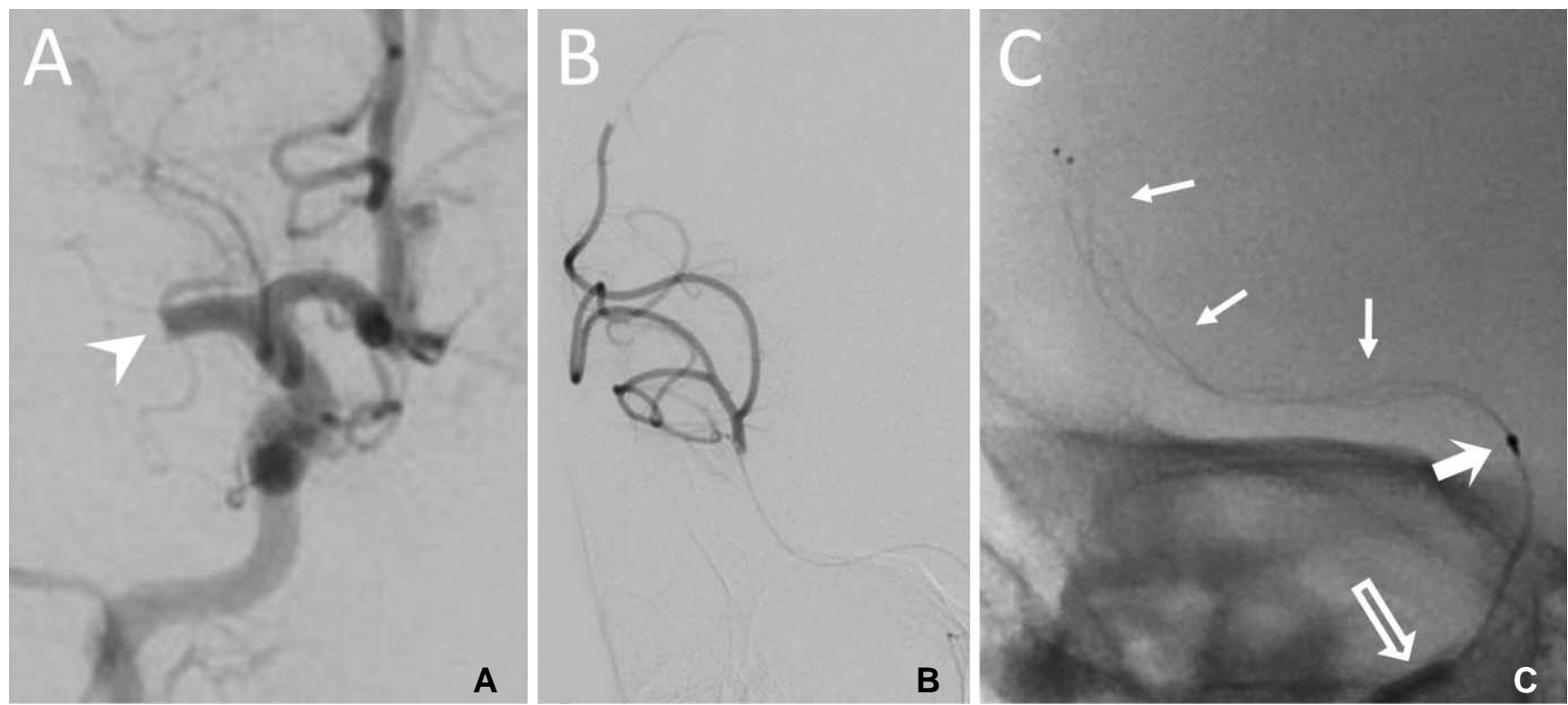

Fig. 2. A. Anterior-posterior (AP) catheter angiogram of a right internal carotid injection demonstrating occlusion of the proximal M1 segment (arrowhead). B. AP angiogram of an injection through a microcatheter passed through the M1 segment thrombus demonstrating distal opacification of the right MCA territory. C. A $3 \times 20 \mathrm{~mm}$ stent retriever (arrows) is deployed through the M1 thrombus. The $3 \mathrm{x}$ $20 \mathrm{~mm}$ stent retriever has 2 radiopaque distal markers. The distal radiopaque marker of the microcatheter is visible proximal to the stent (bold arrow) and the 4F guide catheter is just visible (arrow outline).
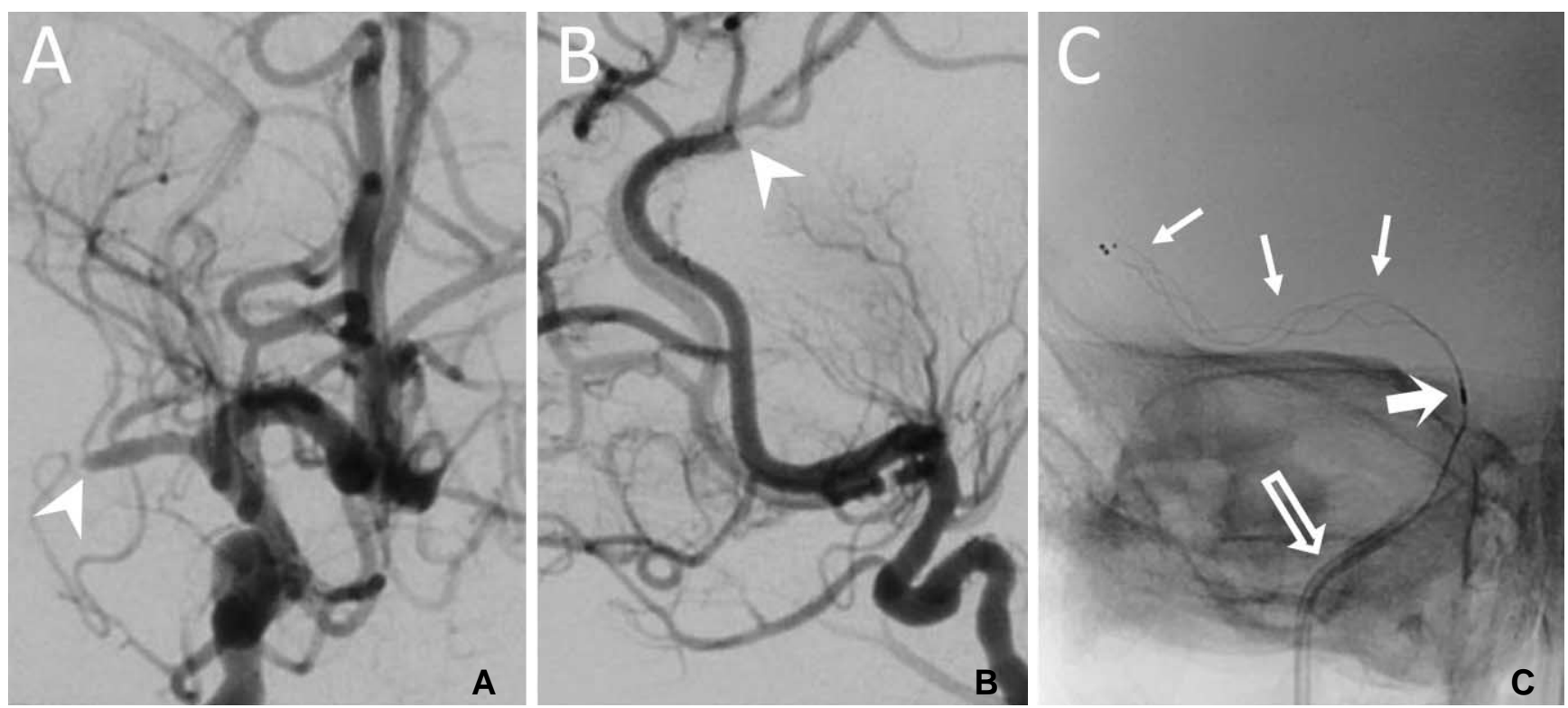

Fig. 3. After the first pass of the $3 \times 20 \mathrm{~mm}$ stent retriever, thrombus (arrowhead) remained in the right $\mathrm{M} 1$ segment $(\mathbf{A})$ and a thrombus fragment (arrowhead) migrated into the distal right ACA distribution shown on the lateral angiogram (B). A larger $4 \times 20 \mathrm{~mm}$ stent retriever (arrows) was deployed through the thrombus in the M1 segment (C). The $4 \times 20 \mathrm{~mm}$ stent retriever has 3 distal markers and the distal marker of the microcatheter is noted proximal to the stent (bold arrow). The 4F guide catheter is visible (arrow outline). 


\section{Pediatric Mechanical Thrombectomy}

withdrawn, leaving only the guide catheter and stent retriever in place. The stent was allowed to incorporate into the thrombus over a period of approximately 3 minutes, and then aspiration was applied to the $4 \mathrm{~F}$ guide catheter in the ICA as the stent retriever was withdrawn. The resulting cerebral angiogram showed a partial reperfusion in the right MCA territory and complete reperfusion in the right ACA territory (Fig.
5). The puncture to recanalization time for the procedure was 55 minutes and time from symptom onset to full recanalization was 7 hours. The guide catheter and sheath were removed and pressure was held to the groin for 15 minutes.
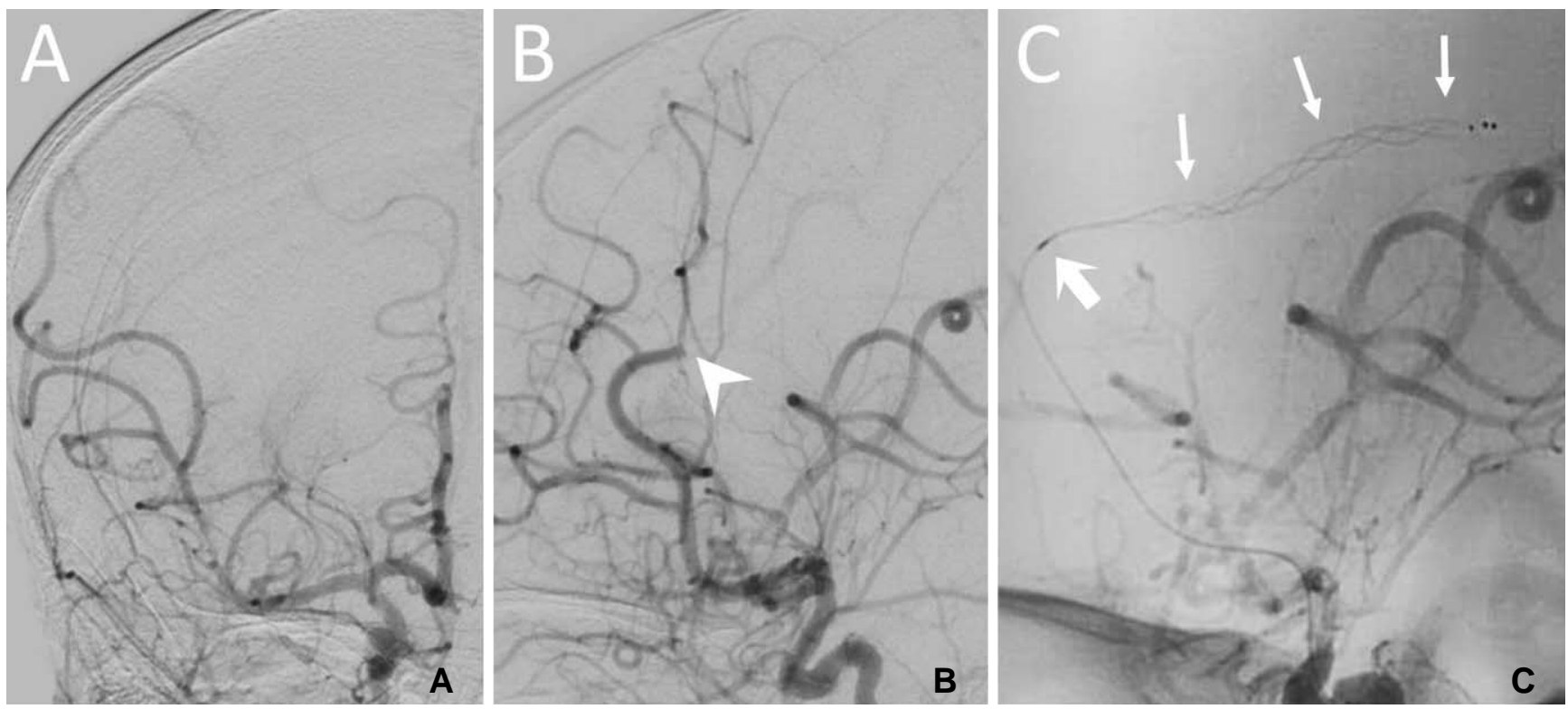

Fig. 4. A. An anterior-posterior angiogram showing robust distal opacification of the right MCA distribution after a successful thrombectomy from the M1 segment using a third pass of a stent retriever. Prior to withdrawal of the last stent retriever, the microcatheter was carefully withdrawn and careful aspiration was applied to the 4F guide catheter in the ICA while the stent was withdrawn. B. The thrombus in the distal ACA distribution (arrowhead) remained after the clot was removed from the M1 segment. C. A $4 \times 20$ mm stent retriever (arrows) is deployed through the thrombus in the right ACA. The distal marker of the microcatheter is proximal to the stent (bold arrow).
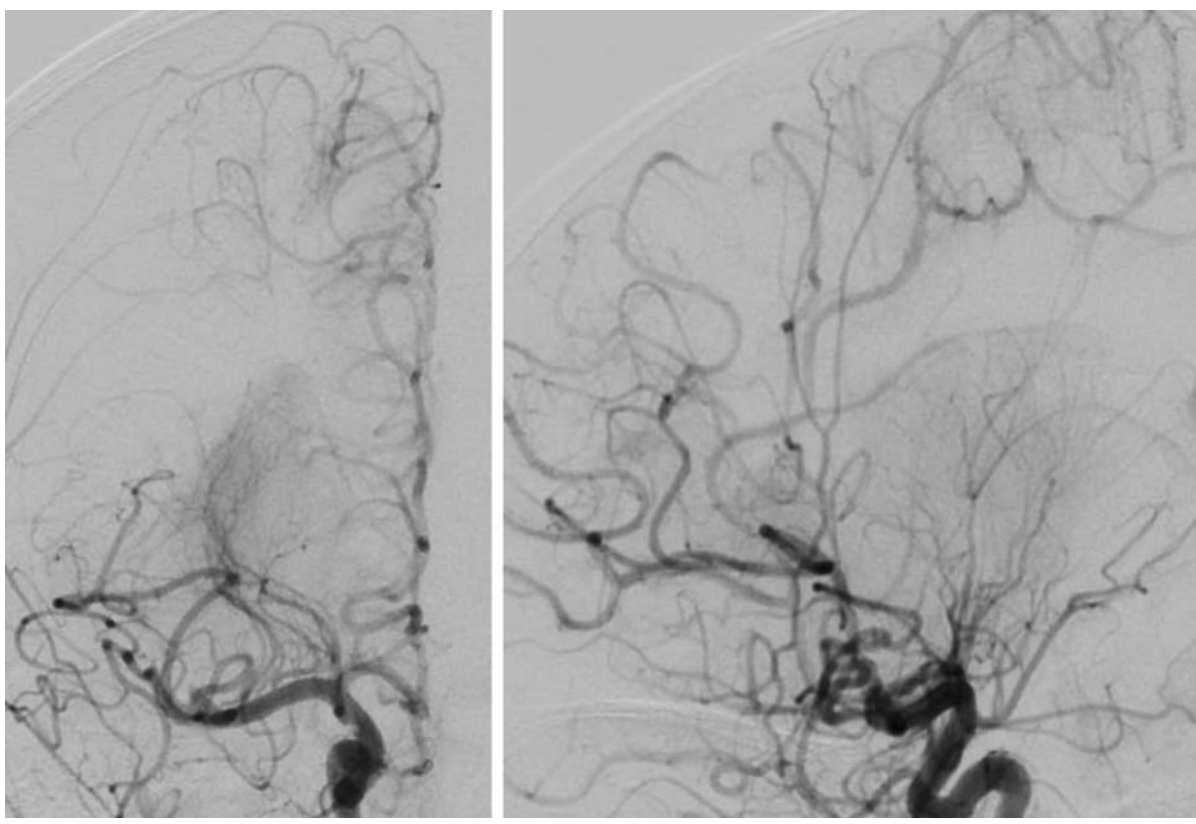

Fig. 5. Anterior-posterior and lateral cerebral arterial phase angiograms after successful mechanical thrombectomies resulting in a partial reperfusion in the right MCA territory and complete reperfusion in right ACA territory. 


\section{David A. Stidd, et al.}

\section{Clinical Outcome}

The patient was extubated at the end of the procedure and admitted to the pediatric intensive care unit. At that time, he was moving all of his extremities, but was weaker on the left side. An MRI obtained on the following day did show an increased area of restricted diffusion deep to the insular cortex. He was placed on a heparin infusion as a bridge while warfarin was restarted with a goal INR of 2.0-2.5. The strength in his left arm and leg continued to improve over the course of his hospitalization and was discharged home after a week. At a 30 day return outpatient clinical visit, he was walking normally with only a mild motor deficit in his left hand and a slight facial droop. His $\mathrm{mRS}$ at that time was 1 .

\section{DISCUSSION}

AIS in childhood is rare with an estimated incidence of 2.5-13 per 100,000 per year [2]. While the mortality rate of pediatric AIS is only $3-6 \%, 70 \%$ of cases will have lifelong morbidity, burdening society for decades after the event [3]. This morbidity is higher than the estimated 50\% morbidity of adult AIS [4] and may be attributed to delayed diagnosis. Signs and symptoms of AIS in the pediatric population can mimic other disease processes, contributing to the median 25 hour delay from clinical onset to radiologic confirmation of pediatric AIS [5].

Treatment for pediatric AIS poses unique challenges. With the exclusion of patients less than 18-year-old from major stroke treatment trials, current strategies for pediatric AIS management are extrapolated from adult treatment strategies. Recommendations of pediatric AIS at this time are limited to supportive management and anticoagulation using aspirin or heparin $[6,7]$. Thrombolysis with intravenous tissue plasminogen activator ( $\mathrm{tPA}$ ) at the present is only recommended in the setting of clinic research protocols [8]. The maturation of the hemostatic system that occurs throughout childhood illustrates physiologic differences between pediatric and adult populations, manifesting as different dose-related responses and pharmacokinetics of thrombolytic therapy $[1,9]$. Thus, optimal dosing of thrombolysis agents in pediatric AIS is difficult to establish. Formal recommendations for intraarterial (IA) tPA or mechanical thrombectomy for pediatric AIS are also lacking and evidence for these therapies are limited to published case reports.

Mechanical thrombectomy may serve as an important primary treatment of pediatric AIS given that diagnosis is often delayed and appropriate thrombolysis dosing is still uncertain. A review of AIS trials over the past 20 years showed that the recanalization rates have significantly improved, attributable to evolving mechanical thrombectomy technique and technology [10]. Though these trials have excluded pediatric cases, a total of 18 mechanical thrombectomy procedures performed in pediatric cases have been published and are summarized in Table $1[1,8,11-20]$. All of these cases with the exception of one report [13] have had favorable results, indicating that a mechanical thrombectomy can be safely performed for a pediatric patient. The average time to treatment after symptom onset of the reported cases was 12.9 hours, well beyond the recommended 8 hour window for treatment [21]. Anticoagulation was only reported in two cases [13, 17] and either IV or IA thrombolysis infusion was reported in 7 cases $[1,12-14,16,18]$. In two reports where complete thrombus retrieval was not possible, one thrombus was transferred from an M1 branch to an ipsilateral A1 branch with a favorable clinical result [12], and a stent was used in the other case to recannulate an internal carotid artery with a favorable clinical result [17]. Other techniques of IA therapy including angioplasty with or without IA thrombolysis infusion are reported.

The current case is an account of the youngest patient where a mechanical thrombectomy was performed for AIS. As with other pediatric cases of AIS, the acute onset of left hemiplegia was not immediately recognized as an ischemic event and presentation to the emergency department was delayed. In this case, an MRI was ultimately obtained to further characterize and confirm the suspicion of AIS. Once the diagnosis was definitively made, the patient was immediately transferred to the endovascular suite. The anatomy of the 2-year-old patient limited the available access in the right common femoral artery to a 4F sheath, which in turn limited the guide to a $4 \mathrm{~F}$ catheter. Due to concerns regarding the size of the occluded M1 branch, a $3 \times 20$ $\mathrm{mm}$ stent retriever was initially and unsuccessfully used without aspiration. Ultimately, complete retrieval of the thrombus required a larger $4 \times 20 \mathrm{~mm}$ stent retriever and aspiration through the $4 \mathrm{~F}$ guide catheter after the microcatheter was first withdrawn. It was initially thought that the size of the M1 segment in the 2-yearold patient would not accommodate the $4 \times 20 \mathrm{~mm}$ stent, but the larger stent retriever was used without hemorrhagic complication and the patient made a favorable recovery. The size of a stent retriever should be tailored to the specific vascular anatomy of pediatric 
Pediatric Mechanical Thrombectomy

Table 1. Published Cases of Pediatric Acute Ischemic Stroke Treated with Mechanical Thrombectomy

\begin{tabular}{|c|c|c|c|c|c|c|c|c|}
\hline Reference & $\begin{array}{l}\text { Age } \\
\text { Sex } \\
\text { (n) }\end{array}$ & $\begin{array}{l}\text { Occlusion } \\
\text { Location } \\
\text { (n) }\end{array}$ & $\begin{array}{l}\text { Presen- } \\
\text { tation }\end{array}$ & Device & $\begin{array}{l}\text { Adjunctive } \\
\text { Tx } \\
\text { (n) }\end{array}$ & $\begin{array}{l}\text { Time } \\
\text { to Tx } \\
\text { (hr) }\end{array}$ & Outcome & Comment \\
\hline $\begin{array}{l}\text { Zaidat et al. } \\
(2005)^{11}\end{array}$ & $16 \mathrm{M}$ & $\mathrm{BA}$ & mRS 5 & $\begin{array}{l}\text { IN-TIME } \\
\text { retrieval device }\end{array}$ & Angioplasty & & $\mathrm{mRS} 2$ & \\
\hline $\begin{array}{l}\text { Tsivgoulis } \\
\text { et al. }(2008)^{12}\end{array}$ & $6 \mathrm{M}$ & R ICA & NHISS 17 & Merci & $\begin{array}{l}\text { IV tPA, IA } \\
\text { Reteplase }\end{array}$ & 4.5 & $\begin{array}{l}90 \text { days: NIHSS } 2 \\
\text { mRS } 1\end{array}$ & $\begin{array}{l}\text { Unable to completely } \\
\text { retrieve clot, clot } \\
\text { transferred to A1 } 270\end{array}$ \\
\hline $\begin{array}{l}\text { Felker et al. } \\
(2010)^{13}\end{array}$ & $14 \mathrm{M}$ & L M1 & healthy & Merci & $\begin{array}{l}\text { Heparin gtt, } \\
\text { IA tPA }\end{array}$ & & $\begin{array}{l}\text { Dense aphasia, } \\
\text { hemiplegic gait }\end{array}$ & $\begin{array}{l}\text { Merci device broke } \\
\text { resulting in complete M1 } \\
\text { occlusion }\end{array}$ \\
\hline \multirow{3}{*}{$\begin{array}{l}\text { Grunwald } \\
\text { et al. }(2010)^{14}\end{array}$} & $16 \mathrm{~F}$ & BA & NIHSS 36 & Penumbra & IA tPA & 8 & 30 day HINSS 23 & \\
\hline & $7 \mathrm{M}$ & L ICA & NIHSS 26 & Penumbra & & 3 & 30 day NIHSS 0 & \\
\hline & $16 \mathrm{~F}$ & L M1 & NIHSS 26 & Phenox device & IA tPA & 3.5 & 30 day HIHSS 0 & \\
\hline $\begin{array}{l}\text { Taneja et al. } \\
(2011)^{15}\end{array}$ & $14 \mathrm{~F}$ & BA & $\begin{array}{l}\text { Rapid } \\
\text { decline }\end{array}$ & Solitaire stent & & 24 & $\begin{array}{l}30 \text { days: no } \\
\text { neurological deficit }\end{array}$ & \\
\hline $\begin{array}{l}\text { Fink et al. } \\
(2012)^{16}\end{array}$ & $11 \mathrm{M}$ & BA & NIHSS 6 & Solitaire stent & IV tPA & 4 & $\begin{array}{l}90 \text { days: slight } \\
\text { dysarthria }\end{array}$ & \\
\hline $\begin{array}{l}\text { Xavier et al. } \\
(2012)^{17}\end{array}$ & $16 \mathrm{M}$ & R ICA & NIHSS 11 & Penumbra & $\begin{array}{l}\text { Heparin gtt, } \\
\text { ASA, PVX }\end{array}$ & 72 & $\begin{array}{l}90 \text { days: NIHSS } 1 \text {, } \\
\text { mRS } 1\end{array}$ & $\begin{array}{l}\text { Complete recanalization } \\
\text { not possible and } \\
\text { Wingspan stent deployed }\end{array}$ \\
\hline $\begin{array}{l}\text { Dubedout } \\
\text { et al. }(2013)^{8}\end{array}$ & $7 \mathrm{M}$ & BA & $\begin{array}{l}\text { PedNIHSS } \\
20\end{array}$ & $\begin{array}{l}\text { CAPTURE } \\
\text { system }\end{array}$ & & 6 & $\begin{array}{l}5 \text { day PedNIHSS } 0 \text {, } \\
30 \text { day mRS } 0\end{array}$ & \\
\hline \multirow[t]{2}{*}{$\begin{array}{l}\text { Hu et al. } \\
(2013)^{1}\end{array}$} & $7 \mathrm{M}$ & R ICA & NIHSS 17 & $\begin{array}{l}\text { Solitaire stents + } \\
\text { Penumbra }\end{array}$ & IV tPA & & 90 day HINSS 2 & \\
\hline & $9 \mathrm{~F}$ & L ICA & NIHSS 16 & $\begin{array}{l}\text { Solitaire stent + } \\
\text { Penumbra }\end{array}$ & & & $\begin{array}{l}90 \text { day NIHSS } 6 \\
180 \text { day NIHSS } 3\end{array}$ & \\
\hline $\begin{array}{l}\text { Tatum et al. } \\
(2013)^{18}\end{array}$ & $\begin{array}{l}4-17 \\
(4)\end{array}$ & $\begin{array}{l}\mathrm{BA}(3) \\
\mathrm{R} M 1(1) \\
\operatorname{RICA}(1)\end{array}$ & $\begin{array}{l}\text { PedNIHSS } \\
2-17\end{array}$ & $\begin{array}{l}\text { Merci, } \\
\text { Penumbra, or } \\
\text { both }\end{array}$ & IA tPA (1) & $4-20$ & $\begin{array}{l}\text { Mean } 90 \text { day } \\
\text { pediatric } \mathrm{mRS}=1\end{array}$ & \\
\hline $\begin{array}{l}\text { Maza et al. } \\
(2014)^{19}\end{array}$ & $12 \mathrm{~F}$ & R ICA & $\begin{array}{l}\text { PedNIHSS } \\
18\end{array}$ & Solitaire stent & & 8 & 90 day PedNIHSS 1 & \\
\hline $\begin{array}{l}\text { Rhee et al. } \\
(2014)^{20}\end{array}$ & $9 \mathrm{M}$ & L M1 & $\begin{array}{l}\text { PedNIHSS } \\
6 / 10\end{array}$ & Solitaire stent & & & $\begin{array}{l}1 \text { year: ambulatory } \\
\text { attending school }\end{array}$ & $\begin{array}{l}\text { Patient with heart disease } \\
\text { and a VAD suffered } 2 \\
\text { strokes } 1 \text { month apart } \\
\text { both treated with mechan- } \\
\text { ical thrombectomies }\end{array}$ \\
\hline Current report & $2 M$ & R M1 & mRS 4 & Trevo stent & & 7 & 30 day $\mathrm{mRS} 1$ & \\
\hline
\end{tabular}

Abbreviations: ASA: aspirin; BA: basilar artery; IA: intraarterial; ICA: internal carotid artery; IV: intravenous; L: left; mRS: modified Rankin scale; NIHSS: NIH stroke scale; PedNIHSS: pediatric; NIH stroke scale; PVX: Plavix; R: right; tPA: tissue plasminogen activator; Time to Tx: time from symptom onset to recanalization; VAD: ventricular assist device.

patients presenting with AIS. Aspiration through the guide catheter during withdrawal of the stent retriever is also important to prevent thrombus migration. For pediatric patients that can only accommodate a $4 \mathrm{~F}$ guide catheter, the delivery microcatheter must first be withdrawn after the stent retriever is deployed to provide enough space in the guide catheter to apply aspiration. 


\section{David A. Stidd, et al.}

\section{CONCLUSION}

Pediatric AIS is a rare event that is associated with a high incidence of poor neurologic outcomes because of delayed diagnosis and treatment. Evidence for treatment of pediatric AIS is sparse and based on expert opinion extrapolated from adult studies. As demonstrated in a growing number of reported cases, mechanical thrombectomy can be safely performed in the pediatric population. A review of the limited reported cases suggest that the therapeutic window for performing a mechanical thrombectomy in pediatric patient population extends beyond the 8 hour time period established for the adult population. Further studies are warranted.

Conflict of Interest: Dr. Lopes has received consultation fees from Covidien, Stryker, and Penumbra.

\section{References}

1. Hu YC, Chugh C, Jeevan D, Gillick JL, Marks S, Stiefel MF. Modern endovascular treatments of occlusive pediatric acute ischemic strokes: case series and review of the literature. Childs Nerv Syst 2014;30:937-943

2. Arnold M, Steinlin M, Baumann A, Nedeltchev K, Remonda L, Moser SJ, et al. Thrombolysis in childhood stroke: report of 2 cases and review of the literature. Stroke 2009;40:801-807

3. Ellis MJ, Amlie-Lefond C, Orbach DB. Endovascular therapy in children with acute ischemic stroke: review and recommendations. Neurology 2012;79(13 Suppl 1):S158-164

4. Di Carlo A. Human and economic burden of stroke. Age Ageing 2009;38:4-5

5. Srinivasan J, Miller SP, Phan TG, Mackay MT. Delayed recognition of initial stroke in children: need for increased awareness. Pediatrics 2009;124:e227-234

6. Monagle P, Chalmers E, Chan A, DeVeber G, Kirkham F, Massicotte $\mathrm{P}$, et al. Antithrombotic therapy in neonates and children: American College of Chest Physicians Evidence-Based Clinical Practice Guidelines (8th Edition). Chest 2008;133(6 Suppl): 887S-968S

7. Roach ES, Golomb MR, Adams R, Biller J, Daniels S, Deveber $\mathrm{G}$, et al. Management of stroke in infants and children: a scientific statement from a Special Writing Group of the American Heart Association Stroke Council and the Council on Cardiovascular Disease in the Young. Stroke 2008;39:2644-2691

8. Dubedout S, Cognard C, Cances C, Albucher JF, Cheuret E.
Successful clinical treatment of child stroke using mechanical embolectomy. Pediatr Neurol 2013;49:379-382

9. Kuhle S, Male C, Mitchell L. Developmental hemostasis: pro- and anticoagulant systems during childhood. Semin Thromb Hemost 2003;29:329-338

10. Fargen KM, Meyers PM, Khatri P, Mocco J. Improvements in recanalization with modern stroke therapy: a review of prospective ischemic stroke trials during the last two decades. $J$ Neurointerv Surg 2013;5:506-511

11. Zaidat OO, Tolbert M, Smith TP, Alexander MJ. Primary endovascular therapy with clot retrieval and balloon angioplasty for acute basilar artery occlusion. Pediatr Neurosurg 2005;41: 323-327

12. Tsivgoulis G, Horton JA, Ness JM, Patterson D, Brethour M, Abanses JC, et al. Intravenous thrombolysis followed by intraarterial thrombolysis and mechanical thrombectomy for the treatment of pediatric ischemic stroke. J Neurol Sci 2008;275:151153

13. Felker MV, Zimmer JA, Golomb MR. Failure of a clot retrieval device in an adolescent stroke patient. Pediatr Neurol 2010;43: 435-438

14. Grunwald IQ, Walter S, Shamdeen MG, Dautermann A, Roth C, Haass A, et al. New mechanical recanalization devices - the future in pediatric stroke treatment? J Invasive Cardiol 2010;22:63-66

15. Taneja SR, Hanna I, Holdgate A, Wenderoth J, Cordato DJ. Basilar artery occlusion in a 14-year old female successfully treated with acute intravascular intervention: case report and review of the literature. J Paediatr Child Health 2011;47:408-414

16. Fink J, Sonnenborg L, Larsen LL, Born AP, Holtmannspotter M, Kondziella D. Basilar Artery Thrombosis in a Child Treated With Intravenous Tissue Plasminogen Activator and Endovascular Mechanical Thrombectomy. J Child Neurol 2013;28:1521-1526

17. Xavier A, Kansara A, Majjhoo AQ, Norris G. CT perfusion guided delayed recanalization with favorable outcome in pediatric stroke. J Neurointerv Surg 2012;4:e33

18. Tatum J, Farid H, Cooke D, Fullerton H, Smith W, Higashida R, et al. Mechanical embolectomy for treatment of large vessel acute ischemic stroke in children. J Neurointerv Surg 2013;5:128-134

19. Sainz de la Maza S, De Felipe A, Matute MC, Fandino E, Mendez JC, Morillo P, et al. Acute ischemic stroke in a 12-year-old successfully treated with mechanical thrombectomy. J Child Neurol 2014;29:269-273

20. Rhee E, Hurst R, Pukenas B, Ichord R, Cahill AM, Rossano J, et al. Mechanical embolectomy for ischemic stroke in a pediatric ventricular assist device patient. Pediatr Transplant 2014;18:E8892

21. Fields JD, Lindsay K, Liu KC, Nesbit GM, Lutsep HL. Mechanical thrombectomy for the treatment of acute ischemic stroke. Expert Rev Cardiovasc Ther 2010;8:581-592 